Arab Univ. J. Agric. Sci., Ain Shams Univ., Cairo, 13(3), 733-740, 2005

\title{
CYTOGENETIC EFFECTS OF Myrtus communis AND Plantago albicans INFUSIONS ON BEAN ROOT-TIP AND MICE BONE-MARROW CELLS
}

\section{[48]}

\author{
Al-Saadi' ${ }^{\text {, M.H.; F.A. Benkhayal }}{ }^{2}$ and A.H. Al-Saadi ${ }^{1}$
}

\begin{abstract}
In Libya the plants Myrtus communis and Plantago albicans are commonly used in folk medicine to treat various diseases. However, there are a large number of plant compounds which can cause many aberrations in genetic material. This study was carried out to investigate any possible cytotoxic and mutagenic effects for $M$. communis and $P$. albicans on mitotic criteria of cell cycle and chromosomes. Two infusion concentrations were prepared for each plant, one of them was used as folk medicine $(0.25 \mathrm{mg} / \mathrm{ml})$ and other as to 10 times of this value $(2.5 \mathrm{mg} / \mathrm{mL})$. Bean (Vicia faba, L.) root-tip cells (RTC) and Balb / C mice (Mus musculus) bonemarrow cells (BMC) were used as test systems. The M. communis infusions at both concentrations and the P. albicans infusion at the lower concentration had no statistically significant depressive effect on mitotic criteria of RTC. Where as significant depressive effect on these criteria of RTC was found for the high concentration of $P$. albicans as compared with a negative control. No significant effect on the induction of chromosome aberrations and the rate of mitotic index of $\mathrm{BMC}$ was found by using infusions of $P$. albicans and $M$. communis as compared with control.
\end{abstract}

Key words: Cytogenetic, Myrtus communis, Plantago albicans, Infusions.

\section{INTRODUCTION}

In Libya, the majority of the population uses traditional natural preparations derived from plant material for treating a variety of disease, and because of this it is extremely important that genotoxicity tests are applied to the active ingredients of these preparations in order to assess their mutagenic potential. The plants Myrtus communis (Myrtaceae) and Plantago albicans (Plantaginaceae) are commonly used in popular Libyan medicine.

The fresh and dry leaves of $M$. communis are used as an infusion to lower the blood glucose level in type- 2 diabetic patients and to treat ulcers and

1- Department of Biology, Faculty of Science, University of Omar El-Mukhtar, Bani Ghazi, Libya.

2- Department of Food Science \& Technology, Faculty of Agriculture, Omar ElMukhtar University, Beni Ghazi, Libya. 
Arab Univ. J. Agric. Sci., Ain Shams Univ., Cairo, 13(3), 733-740, 2005

gastritis (Sepici et al 2004). All myrtle extracts were very rich with polyphenols, flavonol glycosides and hydrolysable tannins (galloyl-glucosides, ellagitannins, galloyl-quinic acids) (Romani et al 2004).

All plant parts except of $P$. albicans are used as an infusion in folk medicine for treating infectious diseases related to the respiratory, urinary and digestive tracts (Chiang et al 2003). The tissues of this plant contain the phenolic compounds, especially caffeic acid (Chiang et al 2002). The research reported in this paper used bean (Vicia $\mathrm{faba}$ ) root-tip cells and $\mathrm{Balb} / \mathrm{C}$ mice $(M u s$ musculus) bone-marrow cells assays to assess whether these plants have any effect on mitotic index or the occurrence of chromosome aberrations.

\section{MATERIAL AND METHODS}

\section{Plant materials}

Myrtus communis and Plantago albicans were obtained from the flora of Wadi Al-Koof, Al- Jabal Al-Akhdar, ALBaida,Libya. Infusions were prepared in the same way as is normally done when they are used by the general population. The M. communis or $P$. albicans leaves (in natura) were boiled for five minutes in tap water, and the infusion was covered and allowed to cool. The infusions from both plants were prepared at two concentrations, one corresponding to that normally used by the general population and the other at a concentration ten times higher by evaporator of stock solution, i.e. 0.25 and $2.5 \mathrm{mg} / \mathrm{mL}$ for each plant.

\section{Root-tip cells}

Bean legumes were placed on filter paper inside Petri-dish containing aerated water at room temperature until rooted, After which root samples were taken to act as time-zero (t zero) controls. Some legumes were then placed in the infusions prepared above (controls were put in water) for $24 \mathrm{~h}$, after which more roots were removed and the legumes were returned to water for 24 to observe if there was recovery from any possible damage. The roots were fixed and stained using the Feulgen reaction and permanently mounted on slides. The slides were examined by using an optical microscope with a $40 \mathrm{X}$ objective. For each legume 1000 cells were analyzed, i.e. a total of 5000 cells each for the control, treatment and recovery groups. Cells with morphological structural alterations were recorded and the mitotic index (MI) of the cells was calculated. The statistical evaluation was performed using the $\chi^{2}$ test at a probability level of 0.05 .

\section{Bone marrow cells}

1- Department of Biology, Faculty of Science, University of Omar El-Mukhtar, Bani Ghazi, Libya.

2- Department of Food Science \& Technology, Faculty of Agriculture, Omar ElMukhtar University, Beni Ghazi, Libya. 
Cytogenetic effects of Myrtus communis and Plantago albicans infusions

Balb / C mice with a body weight (b.w.) of about 23-27g were obtained from the Biology Department, Faculty of Science, University of Omar El-Mukhtar, Three male and three female mice being used for each group (treatments and control). For each group, live mice were injected intraperitoneally for $24 \mathrm{~h}$ with 1 $\mathrm{mL}$ of one of the infusions prepared above, positive control animals being treated with $20 \mathrm{mg}$ of cyclophosphamide (CP) $/ \mathrm{kg} \mathrm{b.w.} \mathrm{All} \mathrm{mice} \mathrm{were} \mathrm{injected} \mathrm{with}$ $0.5 \mathrm{~mL} / 100 \mathrm{~g}$ b.w. of a $0.16 \%$ colchicine solution an hour-and-a-half before sacrifice, bone marrow cells being obtained by modification of the method of Ford and Hamerton (1956).

Chromosome analysis was carried out using optical microscopy and a $100 \mathrm{X}$ immersion lens. For each mouse, 100 metaphases were examined 500 metaphases each for the control and treatment groups. Mitotic index values were calculated for the 5000 cells by sex (a total of 10000 cells/group). Statistical evaluation was performed using he $\chi^{2}$ test at a probability level of 0.05 .

\section{RESULTS AND DISCUSSION}

In the case of $M$. communis the mitotic index of the root-tip cells decreased after $24 \mathrm{~h}$ in each concentration of extract, with a lower mean mitotic index occurring at the higher concentration (Table 1). This effect remaining even after the legumes was subjected to a $24 \mathrm{~h}$ recovery period in water, although the results were not significant according to the $\chi^{2}$ test. For $P$. albicans the mitotic index of the root-tip cells also decreased after $24 \mathrm{~h}$ in each concentration of extract with the difference being statistically significant only for the higher concentration of 2.5 $\mathrm{mg} / \mathrm{mL}\left(\chi^{2}=5.97\right)$. After recovery in water for $24 \mathrm{~h}$ there was a small increase in mitotic index, which although not significant, was well below the mitotic index of the $t$ zero controls $\left(\chi^{2}=4.49\right)$.

Table 1. Mitotic index of bean root-tip cells treated with Myrtus communis (Mc) and Plantago albicans $(\mathrm{Pa})$ infusion

\begin{tabular}{|cccccccc|}
\hline \multirow{2}{*}{ Groups } & $\begin{array}{c}\text { Treatment } \\
\text { time }\end{array}$ & $\begin{array}{c}\text { Mitotic } \\
\text { index }\end{array}$ & Interphase & Prophase & $\begin{array}{c}\text { Metaph } \\
\text { ase }\end{array}$ & $\begin{array}{c}\text { Anaphas } \\
\mathrm{e}\end{array}$ & $\begin{array}{c}\text { Teloph } \\
\text { ase }\end{array}$ \\
\hline Control & control & 10.1 & 4541 & 225 & 93 & 84 & 57 \\
& Treated & 9.3 & 4572 & 165 & 123 & 84 & 56 \\
& Recovery & 9.2 & 4576 & 242 & 93 & 60 & 29 \\
Mc & control & 12.0 & 4461 & 319 & 104 & 80 & 36 \\
$(0.25)$ & & & & & & & \\
& Treated & 9.5 & 4564 & 263 & 98 & 48 & 27 \\
& Recovery & 7.9 & 4630 & 171 & 123 & 49 & 27 \\
Mc (2.5) & control & 13.0 & 4422 & 342 & 112 & 82 & 42 \\
& Treated & 5.1 & 4755 & 158 & 65 & 14 & 8 \\
& Recovery & 4.7 & 4774 & 121 & 75 & 20 & 10 \\
Control & control & 4.6 & 4780 & 144 & 39 & 16 & 21
\end{tabular}


Arab Univ. J. Agric. Sci., Ain Shams Univ., Cairo, 13(3), 733-740, 2005

\begin{tabular}{|cccccccc|} 
& Treated & 2.7 & 4864 & 98 & 32 & 2 & 4 \\
& Recovery & 3.4 & 4835 & 98 & 56 & 6 & 5 \\
$\mathrm{~Pa}$ & control & 5.2 & 4749 & 144 & 55 & 27 & 25 \\
$(0.25)$ & & & & & & & \\
& Treated & 3.6 & 4823 & 101 & 61 & 14 & 1 \\
& Recovery & 4.2 & 4798 & 134 & 39 & 23 & 6 \\
$\mathrm{~Pa}(2.5)$ & control & 8.7 & 4599 & 262 & 82 & 31 & 26 \\
& Treated & $0.8 *$ & 4957 & 22 & 14 & 4 & 3 \\
& Recovery & 1.9 & 4902 & 7 & 25 & 1 & 1 \\
\hline
\end{tabular}

1. The number of cells analyzed in each group was 5000. concentration of infusion in $\mathrm{mg} / \mathrm{mL}$ in parenthesis.

2. Treatment time: Control $=0 \mathrm{~h}(\mathrm{t}$ zero), Treated $=24 \mathrm{~h}$, Recovery $=24 \mathrm{~h}$.

* Statistically significant.

1- Department of Biology, Faculty of Science, University of Omar El-Mukhtar, Bani Ghazi, Libya.

2- Department of Food Science \& Technology, Faculty of Agriculture, Omar ElMukhtar University, Beni Ghazi, Libya.

(Received February 21, 2005)

(Accepted March 16, 2005) 
Arab Univ. J. Agric. Sci., Ain Shams Univ., Cairo, 13(3), 733-740, 2005

Neither of the $M$. communis infusions, nor the $0.25 \mathrm{mg} / \mathrm{mL} P$. albicans infusion, produced a permanent significant depressive mitotic effect on the root-tip cells, although there was a statistically significant temporary inhibition of cellular division in the more concentrated $M$. communis infusion $(2.5$ $\mathrm{mg} / \mathrm{mL}$ ), but this effect was reversible.

In spite of the infusions having caused a decrease in cellular division in root-tip cells compared with non-treated controls only the higher concentration of $P$.

albicans showed a significant inhibitory effect, although this cytotoxic effect was reversible with slight recovery in cell division after $24 \mathrm{~h}$ recovery in water. It is possible that a high concentration of any chemical will have an effect (inhibitory or stimulatory) on the cell cycle, as has been shown for caffeine in Drosophila prosaltans (Itoyama et al 1997), mefloquine in human blood lymphocytes (Grisolia et al 1995), Alpinia mutans and Pogostemun heyneanus extracts in $A$. cepa root-tip cells (Dias and Takahashi, 1994) and glaucolide B extracted from Vemonia eremphila Mart. in human lymphocytes (Burim et al 1999).

\section{Mouse bone marrow cells}

The results showed that there was no significant increase in the number of chromosome alterations in bone-marrow cells from animals treated with any of the infusions prepared from either $M$.

communis or $P$. albicans, nor was there any alteration in the cellular division index as compared with the negative control (Table 2).

Table 2. Mitotic index and chromosome aberrations of bone-marrow cells of Balb/C mice treated with Myrtus communis (Mc) and Plantago albicans $(\mathrm{Pa})$ infusion

\begin{tabular}{|c|c|c|c|c|c|c|}
\hline Groups & $\begin{array}{l}\text { Mitotic } \\
\text { index }\end{array}$ & $\begin{array}{c}\text { Total } \\
\text { alteratio } \\
\mathrm{n}\end{array}$ & $\begin{array}{l}\text { Chroma } \\
\text { tid gap }\end{array}$ & $\begin{array}{c}\text { Chromo } \\
\text { some } \\
\text { gap }\end{array}$ & $\begin{array}{c}\text { Chromati } \\
\text { d break }\end{array}$ & $\begin{array}{c}\text { Chromo } \\
\text { some } \\
\text { break }\end{array}$ \\
\hline Control & 2.2 & 1 & 1 & 0 & 0 & 0 \\
\hline Positive control & 2.2 & 102 & 7 & 0 & 57 & 38 \\
\hline $\operatorname{Mc}(0.25)$ & 2.9 & 2 & 1 & 1 & 0 & 0 \\
\hline $\operatorname{Mc}(2.5)$ & 2.7 & 0 & 0 & 0 & 0 & 0 \\
\hline D. $(\cap \cap)$ & 36 & 2 & 2 & $n$ & $n$ & $n$ \\
\hline
\end{tabular}

1- Department of Biology, Faculty of Science, University of Omar El-Mukhtar, Bani Ghazi, Libya.

2- Department of Food Science \& Technology, Faculty of Agriculture, Omar ElMukhtar University, Beni Ghazi, Libya. 
Arab Univ. J. Agric. Sci., Ain Shams Univ., Cairo, 13(3), 733-740, 2005

The number of cells analyzed in each group was 500. Positive control rats were injected with 20 $\mathrm{mg}$ cyclophosphamide/kg body weight. Concentration of infusion in $\mathrm{mg} / \mathrm{mL}$ in parenthesis.

1- Department of Biology, Faculty of Science, University of Omar El-Mukhtar, Bani Ghazi, Libya.

2- Department of Food Science \& Technology, Faculty of Agriculture, Omar ElMukhtar University, Beni Ghazi, Libya.

(Received February 21, 2005)

(Accepted March 16, 2005) 
Arab Univ. J. Agric. Sci., Ain Shams Univ., Cairo, 13(3), 733-740, 2005

Yen and Chen (1994) found that the principal components of tea leaves and their extracts are catechins, which seem to be responsible for antimutagenic activity, which varied from $4.3 \%$ in black tea to $26.7 \%$ for green tea. Green tea is produced from non-fermented Thea sinensis leaves (the most popular beverage in the orient) much used in Japan as an antipyretic, diuretic and antioxidant, and which has been shown to have antimutagenic and antitumor effects in vitro and in vivo (Kada et al 1985; Shimoi et al 1986; Jain et al 1989 and Wang et al 1989). They, showed that the mortality rate due to human cancers in areas of tea cultivation is significantly lower than in areas where tea is not grown (Sasaki et al 1993), and that the catechin present in green tea suppresses the action of many environmental mutagens (Nakamura et al 1997). Black tea also has high antimutagenic activity in vitro, which varies according to the extent of fermentation of the tea during the manufacturing process (Yen \& Chen, 1994 and Apostolides et al 1996). It has also been reported that black and green teas, without caffeine, have a chemopreventive dose-dependent effect in preventing liver and lung cancer in rats (Cao et al 1996).

Horikawa et al (1994) assessed the activity of six Chinese medicinal herbs on Salmonella and found that tannin and catechin compounds were responsible for the inhibition of mutagenicity caused by benzo [a] pirene.

In a study involving the mutagenic effects of 2-(2-furyl)-3-(5-nitro-2-furyl) (AF-2), Ohtsuka et al (1995) investigated the antimutagenic effects of nine active compounds from the Chinese medicinal herb, and found that the main active antimutagenic compounds were the saponins and the flavonoids. According to Bu-Abbas et al (1996) the high concentration of flavonoids in green tea compared with black tea may mean that these compounds are one of those responsible for the antimutagenic and (possibly) anticarcinogenic properties of tea and its fermented products.

Plantago species exhibited cytotoxic activity, showing a certain degree of selectivity against the tested cells in culture. Since the flavonoids are able to strongly inhibit the proliferation of human cancer cell lines, we have identified luteolin-7-O-beta-glucoside as major flavonoid present in most of the Plantago species (Galvez et al 2003 ). Aqueous extract of Myrtus communis witch contain flavonoids exhibited antigenotoxic and free-radical scavenging activities and the highest level of protection towards aflatoxin $\mathrm{B} 1$ (AFB1) and nifuroxazide was investigated in a bacterial assay system (Hayder et al 2004 ).

It may be considered that the presence of flavonoids, phenolics and tannins in $M$. communis and $P$. albicans was the

1- Department of Biology, Faculty of Science, University of Omar El-Mukhtar, Bani Ghazi, Libya.

2- Department of Food Science \& Technology, Faculty of Agriculture, Omar ElMukhtar University, Beni Ghazi, Libya. 
reason why these medicinal plants did not show cytotoxic and clastogenic effects when tested in our system. It is also possible that extracts of these plants may have antimutagenic effects in different test systems, since the literature cited above indicates that plants containing flavonoids and tannin-like compounds can have such an effect. Our results indicate that the consumption of infusions made from $M$. communis and $P$. albicans can be continued, although they should be used with caution always exactly following the traditional methods of preparation, especially with regards to the concentration of the infusions and the duration of treatment, so that the infusions have the desired pharmacological effects without toxicity. Medicinal plants can be very useful, but it is still necessary for the general population to take care not to use such plants indiscriminately.

\section{REFERENCES}

Apostolides Z.; D.A. Balentine; M.E. Harbowy and J.H. Weisburger (1996). Inhibition of 2-amino-1-methyl-6phenylimidazo[4,5-b]pyridine (PhIP) mutagenicity by black and green tea extracts and polyphenols. Mutation Res. 359: 159-163.

Bu-Abbas, A.; X. Nunez; M.N. Clifford; R. Walker and C. Ioannides (1996). A comparison of the antimutagenic potential of green, black and decaffeinated teas: contribution of flavanols to the antimutagenic effect.

Mutagenesis 11: 597-603.

Burim, R.V.; R. Canalle; J.L.C. Lopes and C.S. Takahashi (1999). Genotoxic action of the sesquiterpene lactone glaucolide B on mammalian cells in vitro and in vivo. Genetics and Molecular

Biology 22:401-406.

Cao, J.; Y. Xu; J. Chen and J.E. Klaunig (1996). Chemopreventive effects of green and black tea on pulmonary and hepatic carcinogenesis.

Fundamental and Applied Toxicology 29:244-250.

Chiang, L.C.; W. Chiang; M.Y. Chang; L.T. Ng and C.C. Lin (2002). Antiviral activity of Plantago major extracts and related compounds in vitro. Antiviral Res. 55 (1): 53-62.

Chiang, L.C.; W. Chiang; M.Y. Chang and C.C. Lin (2003). In vitro cytotoxic, antiviral and immunomodulatory effects of Plantago major and Plantago asiatica. Am. J. Chin Med 31(2): 225-34. Dias, F.L. and C.S. Takahashi (1994). Cytogenetic evaluation of the effect of aqueous extracts of the medicinal plants Alpinia nutans Rosc (Zingiberaceae) and Pogostemun heyneanus Benth (Labiatae) on wistar rats and Allium cepa Linn. (Liliaceae) root tip cells. Rev. Brasil. Genet. 17:175-180.

Ford, C.E. and J.L. Hamerton (1956). A colchicine, hypotonic citrate, squash sequence for mammalian chromosome.

Stain Technology. 31:247-251. Galvez, M.; C. Martin-Cordero; M. Lopez-Lazaro; F. Cortes and M.J. Ayuso (2003). Cytotoxic effect of Plantago spp. on cancer cell lines. $\boldsymbol{J}$. Ethnopharmacol. 88(2-3):125-30 Grisolia, C.K.; C.S. Takahashi and I. Ferrari (1995). In vitro and in vivo tests in humans confirm that the antimalarial drug mefloquine is not mutagenic.

Brazilian J. of Genetics 18:611-615. Hayder, N.; A. Abdelwahed; S. Kilani; R.B. Ammar; A. Mahmoud; K. Ghedira and L. Chekir-Ghedira 
9

Cytogenetic effects of Myrtus communis and Plantago albicans infusions

(2004). Anti-genotoxic and free-radical scavenging activities of extracts from (Tunisian) Myrtus communis. Mutation Res. 14; 564(1): 89-95

Horikawa, K.; T. Mohri; Y. Tanaka and H. Tokiwa (1994). Moderate inhibition of mutagenicity and carcinogenicity of benzo[a]pyrene, 1,6dinitropyrene and 3,9-dinitrofluoranthene by Chinese medicinal herbs. Mutagenesis 9: 523-526.

Itoyama, M.M.; H.E. Bicudo and J.A. Cordeiro (1997). Effects of caffeine on mitotic index in Drosophila prosaltans (Diptera). Brazilian J. of Genetics 20: 655-657.

Jain, A.K.; K. Shimoi; Y. Nakamura; T. Kada; Y. Hara and I. Tomita (1989). Crude tea extracts decrease the mutagenic activity of $\mathrm{N}$ - methyl - N' - nitro - N -nitrosoguanidine in vitro and in intragastric tract of rats. Mutation Res. 210:1-8.

Kada, T.; K. Kaneko; S. Matsuzaki; T. Matsuzaki and Y. Hara (1985).

Detection and chemical identification of natural bioantimutagens. A case of green tea factor. Mutation Res. 150:127-132.

Nakamura, T.; Y. Nakazawa; S.

Onizuka; S. Satoh; A. Chiba; K. Sekihashi; A. Miura; N. Yasugahira and Y.F. Sasaki (1997).

Antimutagenicity of Tochu tea (an aqueous extract of Eucommia ulmoides leaves): 1 . The clastogen - suppressing effects of Tochu tea in CHO cells and mice. Mutation Res. 388:7-20.

Ohtsuka, M.; K. Fukuda; H. Yano and M. Kojiro (1995). Effects of nine active ingredients in Chinese herbal medicine sho-saiko-to on 2-(2-furyl)-3-(5-nitro-2furyl) acrylamide mutagenicity. Japanese J. of Cancer Res. 86:1131-1135.
Romani, A.; R. Coinu; S. Carta; P. Pinelli; C. Galardi; F.F. Vincieri and F. Franconi (2004). Evaluation of antioxidant effect of different extracts of Myrtus communis L. Free Radic Res. 38(1):97-103. Sasaki, Y.F.; H. Yamada; K. Shimoi; K. Kator and N. Kinae (1993). The clastogen-suppressing effects of green 
10

Al-Saadi, M.; Benkhayal and A. Al-Saadi

tea, Po-lei tea and Rooibos tea in CHOcells and mice. Mutation Res.

286:221-232.

Sepici, A.; I. Gurbuz; C. Cevik and E. Yesilada (2004). Hypoglycaemic effects of myrtle oil in normal and alloxandiabetic rabbits. J. Ethnopharmacol 93(2-3):311-8.

Shimoi, K.; Y. Nakamura; I. Tomita; Y. Hara and T. Kada (1986). The pyrogallol related compounds reduced UV - induced mutations in Escherichia coli B/r WP2. Mutation Res. 173:239244.

Silva, I.; S.L. Franco; S.L. Molinari; C.I. Conegero; M.H. Miranda Neto; M.LC. Cardoso; D.M.G.Aant'ana and
N.S. Iwanko (1995). Noc oes Sobre o Organismo Humano e Utilizacao de Plantas Medicinais. Assoeste-Editora Educativa, Cascavel-PR, P. 203. Wang, Z.; W.A. Khan; D.R. Bickers and H. Mukhtar (1989). Protection against polycyclic aromatic hydrocarboninduced skin tumor initiation in mice by green tea polyphenols. Carcinogenesis 10:411-415.

Yen, G. and H. Chen (1994).

Comparison of antimutagenic effect of various tea extracts (green, oolong, pouchong and black tea). J. of Food Protection 57:54-58. 
Arab Univ. J. Agric. Sci., Ain Shams Univ., Cairo, 13(3), 733-740, 2005

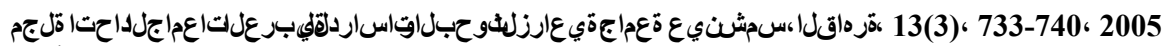

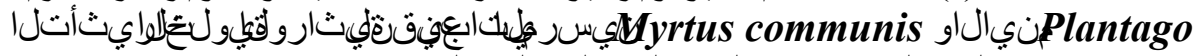

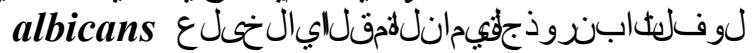

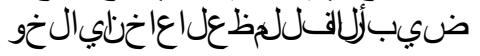

]48[

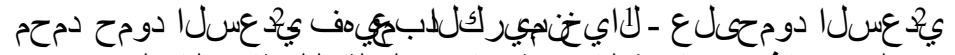

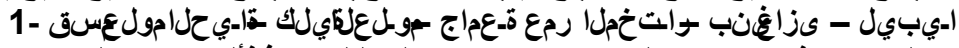

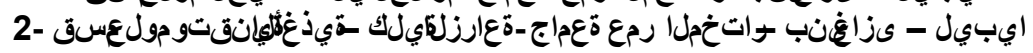

Syrtus

لكشب communis نlantago albicans

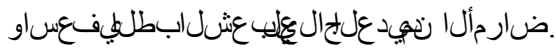

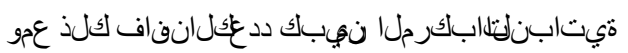

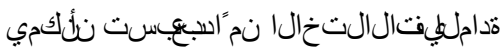

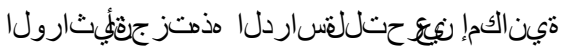

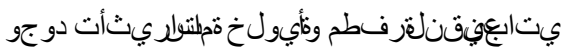

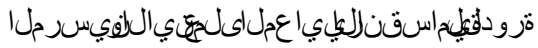

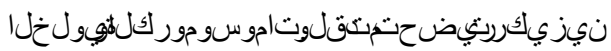

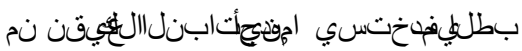

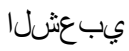
زيكرتبر خآلاو (لم/ججلم 0.25)

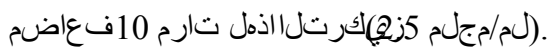

ىنوشلفايز علدي لاملك نزيجيكحت

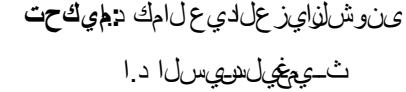

ةمقلايالخصحف اموابت خايجاظخيخ ختسا

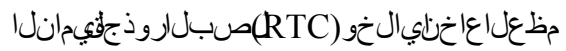

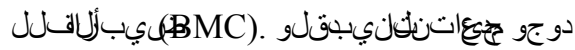

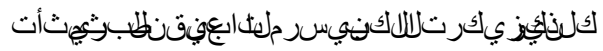

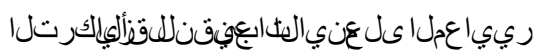

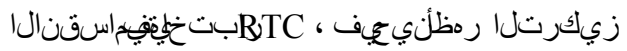

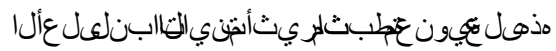

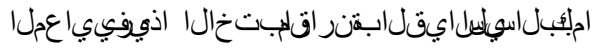

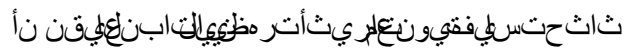

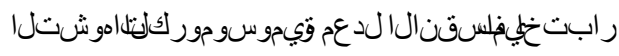

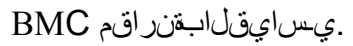

1- Department of Biology, Faculty of Science, University of Omar El-Mukhtar, Bani Ghazi, Libya.

2- Department of Food Science \& Technology, Faculty of Agriculture, Omar ElMukhtar University, Beni Ghazi, Libya. 